\title{
Relationship Between Specificity and Precision in Writing the Main Diagnosis and Accuracy of Main Diagnosis Codes with Financing Claims in Cases of DM in Dr Radjiman Wediodiningrat Hospital, Lawang
}

\author{
Endang Sri Dewi Hastuti Suryandari ${ }^{1}$ \\ ${ }^{1}$ Malang State Health Polytechnic, Malang, Indonesia \\ Correspondence: Endang Sri Dewi Hastuti Suryandari Malang State Health Polytechnic, Malang, Indonesia 65112. \\ Tel: 0341-566075. E-mail: wiwik.esd@gmail.com
}

Received: October 17, 2019; Accepted: September 9, 2019; Published: October 9, 2019

The research is financed by (Sponsoring information).

\begin{abstract}
Specificity and precision in writing the main diagnosis will give the accuracy of diagnosis code, and proper code will give an impact on the appropriate of the cost using INA-CBGs. Research objectives was to analyze the specificity and precision in writing the main diagnosis and the accuracy of main diagnosis code based on ICD-10, also the claims of financing in the case of Diabetes Mellitus (DM) in RSJ Dr. Radjiman Wediodiningrat Lawang, as well as analyzed their relationship. This type of research was a cross sectional correlasional. Independent variables were the specificity and precision in writing the main diagnosis and the accuracy of main diagnosis code, and the dependent variable was the claim of financing. The number of samples analyzed were 50 inpatient medical record document (MRD) of DM cases which hospitalization from January to September 2017, selected by simple random sampling. The results showed the unspecific and unprecise in writing the main diagnosis of DM disease had a risk 1.6 times greater impacting the inaccuracy the main diagnosis code of DM disease (95\% CI: $1.05-2.30$ ) and 1.8 times greater resulting in the claims for financing treatment not accordance (95\% CI: $1.03-3.12)$. An internal verification team is needed for submission of financing claims, consisting of elements from the medical committee, medical recorders and other related elements, as well as conducting periodic monitoring and evaluation of how to write the main diagnoses and their coding.
\end{abstract}

Keywords: specificity and precision in writing the main diagnosis, accuracy of main diagnosis codes, claims financing

\section{Introduction}

The main diagnosis is the most relevant diagnosis during the treatment period and is established at the end of the service episode after a more thorough examination. Determination of the main diagnosis is the responsibility of the doctor who treats the patient during the treatment period, the diagnosis that has been determined by the doctor is one of the important roles in the accuracy of the diagnosis code that will affect the financing system (Shofari, 2002; Permenkes Nomor 76 tahun 2016 tentang Pedoman INA-CBGs Dalam Pelaksanaan Jamkesnas). This coding must be appropriate and in accordance with the directions in the ICD-10 book.

Accurate coding requires a complete and correct medical record, including writing a diagnosis of a disease by a doctor (Hatta, 2013) [3,16]. International Statistical Classification of Diseases and Related Health Problems Tenth Revision $(I C D-10)$ is a reference used in Indonesia to code diagnosis (Keputusan Menteri Kesehatan Republik Indonesia Nomor 844/ MENKES / SK / X / 2006 tentang Penetapan Standar Kode Data Bidang Kesehatan). Some hospitals in Indonesia (around 65\%) have not made a complete and clear diagnosis based on the ICD-10 and have not been properly coded (Departemen Kesehatan Republik Indonesia, 2008). The impact that occurs when writing an incorrect diagnosis is that the patient sacrifices enormous costs, patients who should not take antibiotics but must be given antibiotics and more fatal effects are at risk of life threatening patients (Hatta, 2013). 
Research conducted by Hamid (2013), revealed that there was a significant effect between the accuracy of the writing of the diagnosis and the accuracy of the diagnosis code at $p=0.001$. Inaccuracies in the diagnosis code will affect report data and information as well as the accuracy of INA-CBG's rates, which are currently used as a payment method for services for national health insurance participant patients in Indonesia (Permenkes Nomor 76 tahun 2016 tentang Pedoman INA-CBGs Dalam Pelaksanaan Jamkesnas). Errors in coding the disease, then the claim payment amount will also be different. Low health care rates will certainly harm the hospital, while the high rates for health services seem to benefit the hospital, which is detrimental to the national health insurance administrators and patients. The purpose of this study was to prove the relationship between the specificity and precision in writing the main diagnosis and the accuracy of the main diagnostic code with the financing claims in cases of DM in the Wediodiningrat Lawang Hospital.

\section{Method}

\subsection{Research Design}

The study was carried out in the Medical Record Installation of Wediodiningrat Lawang Hospital by using an observational analytic study design with correlation studies through the cross sectionl approach, namely measuring the specificity and precision in writing the main diagnosis of DM disease, the accuracy of the main diagnosis code of DM disease, as an independent variables and financing claims as dependent variable, which measured at one time. The sample used was a DM case medical record document for inpatients with a number of 50 documents, taken by simple random sampling by selecting MRD by lottery, from 99 medical records inpatient cases of DM disease from January to September 2017.

\subsection{Treatment}

The specificity and precision in writing the main diagnosis is the writing of a diagnosis of an inpatient using the appropriate and detailed medical terminology language according to the classification of DM disease, by the doctor who treat the patient. The specificity and precision in writing the main diagnosis of DM disease was measured by observing the specificity and precision in writing the main diagnosis in the medical record, with a measurement scale: nominal, that is given a score of 2 if the writing of the diagnosis has used the terminology in a precise and detailed language, and score 1 if the diagnosis does not use the terminology language accurately and in detail according to DM classification.

The accuracy of the main diagnostic code is the accuracy of giving a diagnosis code by a coder, based on ICD-10 tenth revision. The ICD-10 tenth revision has been used as a reference for coding diagnosis disease regulated in KEPMENKES RI Number: 844/MENKES/SK/X /2006. The accuracy of the main diagnosis code of DM disease was measured by observing the diagnosis code mainly with a measurement scale: nominal, that is given a score of 2 if the main diagnosis code is determined according to the rules contained in the ICD-10 tenth revision and score 1 if the diagnosis code is not appropriate with the rules contained in the ICD-10 tenth revision. The financing claim is the amount of the fee charged to the patient based on the main diagnosis of the disease assigned to the patient when discharge from the hospital. In this case the cost amount is calculated in accordance with the INA CBGs tariff package system. The method of measurement by examining the amount of the cost that has been determined compared to the cost that should be charged based on the specificity of the correct main diagnosis and accurate code. Measurement scale: nominal, that is, given a score of 2 if the predetermined cost is in accordance with the specificity of the main diagnosis and accurate code, and score 1 if the set cost is not in accordance with the specificity of the main diagnosis and accurate code.

Data collection was further analyzed using double logistic regression test analysis with significance level of 0.05 . This test was to determine the relationship between the specificity and precision in writing the main diagnosis with the accuracy of main diagnosis codes and the claim of financing on DM cases in RSJ Dr Radjiman Wediodiningrat Lawang.

As a follow-up, the FGD was conducted to explore the opinions of medical personnel as the person in charge of writing the patient's disease diagnosis, the Chair of the Medical Committee, the Head of the Medical Record Division, the coding staff and the internal verifier and BPJS verifier.

\subsection{Ethical Clearance}

This study has fulfilled the requirement of ethical committee of experimental research from the Ethic Committee of Polytechnic of Health, The Ministry of Health in Malang, Indonesia number 557/KEPK-POLKESMA/2017. 


\section{Results}

The univariate analysis (Table 1) showed that 14 MRD (28\%) from 50 MRD with cases of diabetes mellitus (DM), the diagnosis were written specifically and precisely; 5 MRD (10\%) the DM diagnosis code were accurate and only 10 MRD (20\%) were paid according to the cost of treating the disease.

Table 1. Results of univariate analysis of independent and dependent variables

\begin{tabular}{|c|c|c|c|}
\hline No & Variabel & Frek. & $\%$ \\
\hline \multirow[t]{3}{*}{1.} & $\begin{array}{l}\text { Specificity and Precision in Writing the } \\
\text { Main Diagnosis. }\end{array}$ & & \\
\hline & $-\quad$ Specific and Precise & 14 & 28 \\
\hline & Unspecific and Unprecise & 36 & 72 \\
\hline \multirow[t]{3}{*}{2.} & Accuracy of the Main Diagnostic Code: & & \\
\hline & - $\quad$ Accurate & 5 & 10 \\
\hline & Not accurate & 45 & 90 \\
\hline \multirow[t]{3}{*}{3.} & $\begin{array}{l}\text { According claims to the cost of treating the } \\
\text { disease: }\end{array}$ & & \\
\hline & - Accordance & 10 & 20 \\
\hline & Not Accordance & 40 & 80 \\
\hline
\end{tabular}

Bivariate analysis using the parametric statistical test ( Pearson Chi-Square test), with a significance level of $\alpha=$ 0.05 .

Table 2. Relationship between the Specificity and Precision in Writing the Main Diagnosis of DM Disease with the Accordance of Claims for Financing Treatment

\begin{tabular}{|c|c|c|c|c|c|c|c|}
\hline \multirow{2}{*}{$\begin{array}{l}\text { Precision and } \\
\text { Specifications of Main } \\
\text { Diagnosis Writing }\end{array}$} & \multicolumn{2}{|c|}{ d Accordance of Claims } & \multirow[b]{2}{*}{ Total } & \multirow[b]{2}{*}{$P$ value } & \multirow{2}{*}{$\begin{array}{l}\text { Relative } \\
\text { Risk } \\
\text { (RR) }\end{array}$} & \multicolumn{2}{|c|}{$95 \%$ CI } \\
\hline & Accordance & $\begin{array}{l}\text { Not } \\
\text { Accordance }\end{array}$ & & & & Lower & Upper \\
\hline Specific and Precise & $7(50 \%)$ & $7(50 \%)$ & $14(100 \%)$ & \multirow[t]{3}{*}{0,001} & \multirow[t]{3}{*}{1,833} & \multirow[t]{3}{*}{1,026} & \multirow[t]{3}{*}{3,124} \\
\hline Unspecific and Unprecise & $3(8,3 \%)$ & $33(91,7 \%)$ & $36(100 \%)$ & & & & \\
\hline Total & $10(20 \%)$ & $40(80 \%)$ & $50(100 \%)$ & & & & \\
\hline
\end{tabular}

The Chi-Square test results showed there were a relationship between the specificity and precision in writing the main diagnosis of DM disease with accordance of claims for financing treatment ( $p$ value $<0.005$ ). Based on the Relative Risk (RR) value, unspecific and unprecise in writing the main diagnosis of DM disease had a risk 1.8 times greater resulting in the claims for financing treatment not accordance $(95 \% \mathrm{CI}: 1.03-3.12)$ compared with the specifically and precisely in writing the main diagnosis of DM disease (Table 2).

Table 3. Relationship between the Accuracy of the Main Diagnosis Code with the Accordance of Claims for Financing Treatment

\begin{tabular}{|c|c|c|c|c|c|c|c|}
\hline & \multicolumn{2}{|c|}{ of the Accordance of Claims } & \multirow[b]{2}{*}{ Total } & \multirow[b]{2}{*}{ P value } & \multirow{2}{*}{$\begin{array}{l}\text { Relative } \\
\text { Risk } \\
\text { (RR) }\end{array}$} & \multirow{2}{*}{$\begin{array}{l}95 \% \text { CI } \\
\text { Lower }\end{array}$} & \multirow[b]{2}{*}{ Uppe I } \\
\hline $\begin{array}{l}\text { Accuracy } \\
\text { Main } \\
\text { Code }\end{array}$ & Accordance & $\begin{array}{l}\text { Not } \\
\text { Accordance }\end{array}$ & & & & & \\
\hline Accurate & $5(100 \%)$ & $0(0 \%)$ & $5(100 \%)$ & $-0,000$ & 0,111 & 0,049 & 0,254 \\
\hline Not Accurate & $5(11,1 \%)$ & $40(88,9 \%)$ & $45(100 \%)$ & & & & \\
\hline Total & $10(20 \%)$ & $40(80 \%)$ & $50(100 \%)$ & & & & \\
\hline
\end{tabular}

The relationship between the accuracy of the main diagnosis code of DM disease and the accordance of claims for financing treatment was analyzed using the Fisher's Exact Test (Table 3), because one of the cells was zero (0) . The Fisher's Exact Test results showed that there were a relationship between the accuracy of the main diagnosis of 
DM disease code with the accordance of claims for financing treatment ( $p$ value $<0.005$ ). Based on the Relative Risk (RR) value, inaccurately the main diagnostic code for DM disease had a risk 0.11 times smaller impacting the accordance of claims for financing treatment (95\% CI: $0.05-0.25)$, compared with the main diagnostic code accurate DM disease, in other words, the main diagnostic of DM disease that code accurately had a risk 9 times greater impacting the accordance of claims for financing treatment.

Table 4. Relationship between the Specificity and Precision in Writing the Main Diagnosis with the Accuracy of the Main Diagnostic Code

\begin{tabular}{|c|c|c|c|c|c|c|c|}
\hline $\begin{array}{l}\text { Precision } \\
\text { Specifications }\end{array}$ & \multicolumn{2}{|c|}{$\begin{array}{l}\text { and Accuracy of the Mair } \\
\text { of Diagnosis Code }\end{array}$} & \multirow{2}{*}{ - Total } & \multirow{2}{*}{$P$ value } & \multirow{2}{*}{$\begin{array}{l}\text { Relative } \\
\text { Risk } \\
\text { (RR) }\end{array}$} & \multicolumn{2}{|c|}{$95 \% \mathrm{CI}$} \\
\hline $\begin{array}{ll}\text { Main } & \text { Diagnosis } \\
\text { Writing } & \\
\end{array}$ & Accurate & Not Accurate & & & & Lower & Upper \\
\hline Specific and Precise & $5(35,7 \%)$ & $9(64,3 \%)$ & $14(100 \%)$ & 0,000 & 1,556 & 1,053 & 2,299 \\
\hline $\begin{array}{l}\text { Unspecific and } \\
\text { Unprecise }\end{array}$ & $0(0 \%)$ & $36(100 \%)$ & $36(100 \%)$ & & & & \\
\hline Total & $5(10 \%)$ & $45(90 \%)$ & $50(100 \%)$ & & & & \\
\hline
\end{tabular}

The relationship between the specificity and precision_in writing the main diagnosis of DM disease with the accuracy of the main diagnostic code of DM disease was analyzed using the Fisher's Exact Test (Table 4), because one of the cells was zero (0). The Fisher's Exact Test results showed that there were a relationship between the specificity and precision_in writing the main diagnosis of DM disease with the accuracy of the main diagnostic code of DM disease ( $p$ value $<0,005$ ). Based on the value of Relative Risk (RR), unspecific and unprecise in writing the main diagnosis of DM disease had a risk 1.6 times greater impacting the inaccuracy the main diagnosis code of DM disease (95\% CI: 1.05 - 2.30), compared with specificity and precision in writing the main diagnosis of DM disease.

Multivariate analysis was analyzed using the Multiple Logistic Regression test, because of the normality test using One-Sample Kolmogorov-Smirnov (K-S) test showed the significance value of each independent variable and the dependent variable are all smaller than 0.05 , which means the datas were abnormally distributed.

Table 5. The results of multivariate analysis using multiple logistic regression tests

\begin{tabular}{lllllll}
\hline VARIABEL & B & S.E. & Wald & df & Sig & Exp (B) \\
\hline $\begin{array}{l}\text { Specificity and Precision_in } \\
\begin{array}{l}\text { Writing the Main Diagnosis } \\
\text { Accuracy of the Main }\end{array}\end{array}$ & 1,145 & 1,003 & 1,303 & 1 &, 254 & 3,143 \\
$\begin{array}{l}\text { Diagnosis Code } \\
\text { Constant }\end{array}$ & $-25,456$ & 17974,845 &, 000 & 1 &, 999 & 5654162718,083 \\
\hline
\end{tabular}

The multiple logistic regression tests (Table 4) showed there were no relationship between the specificity and precision in writing the main diagnosis of DM disease and the accuracy of the diagnosis code of DM disease with the accordance of claims for financing treatment. $(p>0.05)$. However, the results of bivariate analysis showed that there was a relationship between each variable partially.

\section{Discussion}

Based on the integrated patient development record (IPDR) and the results of investigations found in the patient's MRD sheet (MRDs), 6 patients should be diagnosed with Insulin Dependent Diabetes Mellitus (IDDM), but in the medical resume of patients written the diagnosis of Non Insulin Dependent Diabetes Mellitus (NIDDM), and 2 other patients should be diagnosed with Non-Insulin Dependent Diabetes Mellitus (NIDDM), but in the medical resume of patients were diagnosed with Insulin Dependent Diabetes Mellitus (IDDM). The other 28 MRDs indicated the writing of main diagnoses were not specific. If patients only suffer from type I DM without complications, then the the main diagnosis in the patient's medical resume should be written specifically, namely Insulin Dependent Diabetes Mellitus Without Complication. Patient was diagnosed DM type II with complications of polyneuropathy, should be written specifically as Non-Insulin Dependent Diabetes Mellitus Polyneuropathy 
With Neurological Complication. Unspecificity in writing the main diagnosis will cause a difference in determining the diagnosis code. This can be proven, if the main diagnosis listed is only NIDDM, then the diagnosis code is E11. Whereas if the main diagnosis listed is more specific, namely NIDDM Polyneuropathy With Neurological Complication, then the correct diagnostic code is E11.4 $†$ G63.2* (Word Health Organization, 2011). The main diagnosis is the most relevant diagnosis during the treatment period and is enforced at the end of the service period after a more in-depth examination (Shofari, 2002).

The writing of the main diagnosis that was not precise and unspecific causes the determination of the diagnostic code to be inaccurate, resulting in treatment financing claims being inappropriate. (Abdelhak \& Hanken, 2012; Fernandez, 2017; Kveton, 2018; O'Malley, K. J. et al., 2005; Word Health Organization, 2014; Danzi, J. T. et al., 2000). $80 \%$ of MRD that did not match claims for financing treatment were due to incomplete doctor diagnoses that had an impact on inaccurate diagnostic codes, in addition to the use of fourth digits as a complement to improper diagnostic codes. This results in a calculation of financing claims could be lower or even higher than the claim count should be. 3 of the 50 MRDs obtained from the financing claim count which was lower than the supposed claim count, and 1 MRD showed that the calculation of financing claims was higher than the claim count should be (claim calculation was based on the INA-CBGs tariff pattern by using financing standards for class 3 hospitalization).

The patient's medical resume sheets showed that the doctor wrote the main diagnosis using IDDM with multiple complications and the diagnostic code was E10.7, and based on the INA-CBGs tariff pattern, the claim for the patient's episode care cost was Rp. 3,690,400, -. After analyzed the document, the main diagnosis of the patient should be IDDM with peripheral circulatory complications (due to complications in the form of gangrene wounds on the toes and amputation). So that the main diagnostic code becomes E10.5 and the calculation of claims for patient care episode costs becomes Rp. 4,722,500, -. Another MRD showed the writing of DM diagnosis was only written as a diagnosis of IDDM without complications, so the hospital received a financing claim of Rp. 3,690,400, -. The results of re-analyzed of documents obtained by the diagnosis of patients was IDDM with complications of polyneuropathy with payment claims that should be received by the hospital in the amount of Rp. 8,181,700. Both of those cases resulted in a low number of care financing claims received by the hospital.

Calculation of financing claims for the 50 MRD studied, based on diagnoses and codes contained in medical resumes, as well as calculations using financing standards for class 3 inpatient care and based on the INA-CBGs tariff pattern, obtained total hospital income of Rp. 77,805,500, -. Whereas if treated with recalculation using a diagnostic basis and the right code will be obtained total hospital income of Rp. 211,769,940, -. From the calculation difference, it can be concluded that the hospital will experience an income loss of Rp. 133,964,440, -.

The main diagnosis that was not precise and incorrect and an inaccurate diagnostic code can also result in a higher financial claim count than the claim count should be. From 50 MRD, 1 MRD obtained the main diagnosis was NIDDM with Neurogical Complication and the diagnostic code E11.4 and claim for treatment costs was Rp. $6,239,700$, -. After re-analyzed the document obtained the main diagnosis was NIDDM with multiple complications with the correct diagnostic code E11.7 and claims for treatment costs should be Rp. 3,690,400, -. In this case the hospital's financial income was more profitable, but it was detrimental to the patient's side. This situation if done intentionally by the hospital could be classified as a case of "FRAUD " or upcoding. One of the actions of Fraud is the writing of excessive diagnosis code / upcoding, which is the writing of the diagnostic code changed into a code with a higher cost (Peraturan Menteri Kesehatan No.36 Tahun 2015 tentang Fraud; Prophet, 1997; Linder, 2012). The difference between the diagnoses submitted for claims for the cost of care and the actual description of the patient's condition recorded in the medical record documentation is one of Medicare Risk Adjustment Coding Errors (Fernandez, 2017).

The results of Focus Group Discussion (FGD) obtained information that the specialist doctors who conducted medical examinations of patients had listed their medical findings in IPDR, but those who filled the final diagnosis in medical resumes sometimes carried out by general practitioners who were in charge of inpatient rooms. This situation resulted in the writing of main diagnosis sometimes was not presice and unspecific. The general practitioners and internal medicine specialists did not understand about the diagnosis code and the importance of accuracy and specificity in writing the main diagnosis for coding the diagnosis. On the other hand there were lack of communication between specialist doctors and physicians in charge of the room with medical record officers.

The commitment in this group discussion was to evaluate the writing of the diagnosis through regular medical committee meetings perodically and needed to establish an internal hospital verification team that functions as a medical record document verifier to be submitted for financing claims. 


\section{Acknowledgments}

The amount of claims for financing the care of patients with DM disease was closely related to the specifically and precisely of the diagnostic writing and also the accuracy in coding the diagnosis of DM disease. An internal verification team is needed for submission of financing claims, consisting of elements from the medical committee, medical recorders and other related elements, as well as conducting periodic monitoring and evaluation of how to write the main diagnoses and their coding.

\section{References}

Abdelhak, M., \& Hanken, M. A. (2012). Health Information Management of a Strategic Resource. $5^{\text {th }}$ Edition. Elsevier Saunders. 421-691

Danzi, J. T., Masencup, B., Brucker, M. A., \& Dixon-Lee, C. (2000). Case study: clinical documentation improvement program supports coding accuracy. Top Health Inf Manage, 21(2), 24-29. Retrieved from https://www.ncbi.nlm.nih.gov/pubmed/11143276

Departemen Kesehatan Republik Indonesia. (2008). Pedoman Pengelolaan Rekam Medis Rumah Sakit di Indonesia, Revisi 2, Jakarta.

Farhan, J., Al-Jummaa, S., Alrajhi, A. A., Al-Rayes, H., \& Al-Nasser, A. (2005). Documentation and coding of medical records in a tertiary care center: A pilot study. Annals of Saudi Medicine, 25(1), 46-49. https://doi.org/10.5144/0256-4947.2005.46

Fernandez, V. (2017). "Ins and Outs of HCCs." Journal of AHIMA, 88(6), 54-56

Hamid. (2013). Hubungan Ketepatan Penulisan Diagnosis Dengan Keakuratan Kode Diagnosis Kasus Obstetri Gynecology Pasien Rawat Inap di RSUD Dr Saiful Anwar Malang. Retrieved from http://eprints.ums.ac.id/24161/13/NASKAH_PUBLIKASI.pdf, tanggal 1 Nopember 2017

Hatta, G. R. (2013). Pedoman Manajemen Informasi Kesehatan di Sarana Pelayanan Kesehatan, Edisi Revisi 2, Jakarta, Penerbit Universitas Indonesia.

Keputusan Menteri Kesehatan Republik Indonesia Nomor 844/ MENKES / SK / X / 2006 tentang Penetapan Standar Kode Data Bidang Kesehatan.

Kveton, N. (2018). Improving Accuracy of Clinical Documentation Positively Impacts Risk Adjustment Factor and HCC Coding. Posted in Accountable Care, Data Quality, Management \& Governance and Payers \& Providers. HealthCatalyst.

Linder, H. (2012). ASC Coding, Billing, and Collections. 5 Common Fraudulent Coding, Billing Schemes.

O'Malley, K. J., Cook, K. F., Price, M. D., Wildes, K. R., Hurdle, J. F., \& Ashton, C. M. (2005). Measuring Diagnoses: ICD Code Accuracy. Jurnal Health Service Research, 40(5 Pt 2), 1620-1639. https://doi.org/10.1111/j.1475-6773.2005.00444.x

Peraturan Menteri Kesehatan No.36 Tahun 2015 tentang Fraud.

Permenkes Nomor 76 tahun 2016 tentang Pedoman INA-CBGs Dalam Pelaksanaan Jamkesnas.

Prophet, S. (1997). Fraud and Abuse Implications for the HIM Professional. Journal of AHIMA, 68(4), 52-56.

Shofari. (2002). Pengelolaan Sistem Rekam Medis Kesehatan. Semarang.

Word Health Organization. (2011). ICD -10 (International Statistical Classification of Diseases and Related Health Problems), 1, 2, 3. (2010 Edition). ISBN 9789241548342.

Word Health Organization. (2014). ICD 10 - 2010, Update Review 2013. Module Development.

\section{Copyrights}

Copyright for this article is retained by the author(s), with first publication rights granted to the journal.

This is an open-access article distributed under the terms and conditions of the Creative Commons Attribution license (http://creativecommons.org/licenses/by/4.0/). 